\title{
OPEN Author Correction: Drug screening of cancer cell lines and human primary tumors using droplet microfluidics
}

Ada Hang-Heng Wong, Haoran Li, Yanwei Jia, Pui-In Mak, Rui Paulo da Silva Martins, Yan Liu, Chi Man Vong, Hang Cheong Wong, Pak Kin Wong, Haitao Wang, Heng Sun \& Chu-Xia Deng

Correction to: Scientific Reports https://doi.org/10.1038/s41598-017-08831-z, published online 22 August 2017

This Article contains errors in the Results section.

"On the other hand, the width ratio of the neck to the bypass channel was optimized to 3:4 in order to favor fluid flow into the well over the bypass. In this work, three designs were tested: the widths of the neck to the bypass channel were $75 \mu \mathrm{m} / 100 \mu \mathrm{m}, 100 \mu \mathrm{m} / 100 \mu \mathrm{m}$ and $100 \mu \mathrm{m} / 150 \mu \mathrm{m}$, respectively. Results showed that the design of $75 \mu \mathrm{m} / 100 \mu \mathrm{m}$ neck to bypass width favored fluid flow into the well over the bypass channel (Supplementary Movie 2)."

should read:

"On the other hand, the width ratio of the bypass to the neck channel was optimized to 3:4 in order to favor fluid flow into the well over the bypass. In this work, three designs were tested: the widths of the bypass to the neck channel were $75 \mu \mathrm{m} / 100 \mu \mathrm{m}, 100 \mu \mathrm{m} / 100 \mu \mathrm{m}$ and $100 \mu \mathrm{m} / 150 \mu \mathrm{m}$, respectively. Results showed that the design of $75 \mu \mathrm{m} / 100 \mu \mathrm{m}$ bypass to neck width favored fluid flow into the well over the bypass channel (Supplementary Movie 2)."

(i) Open Access This article is licensed under a Creative Commons Attribution 4.0 International License, which permits use, sharing, adaptation, distribution and reproduction in any medium or format, as long as you give appropriate credit to the original author(s) and the source, provide a link to the Creative Commons license, and indicate if changes were made. The images or other third party material in this article are included in the article's Creative Commons license, unless indicated otherwise in a credit line to the material. If material is not included in the article's Creative Commons license and your intended use is not permitted by statutory regulation or exceeds the permitted use, you will need to obtain permission directly from the copyright holder. To view a copy of this license, visit http://creativecommons.org/licenses/by/4.0/.

(C) The Author(s) 2019 